CANCER CELL

INTERNATIONAL

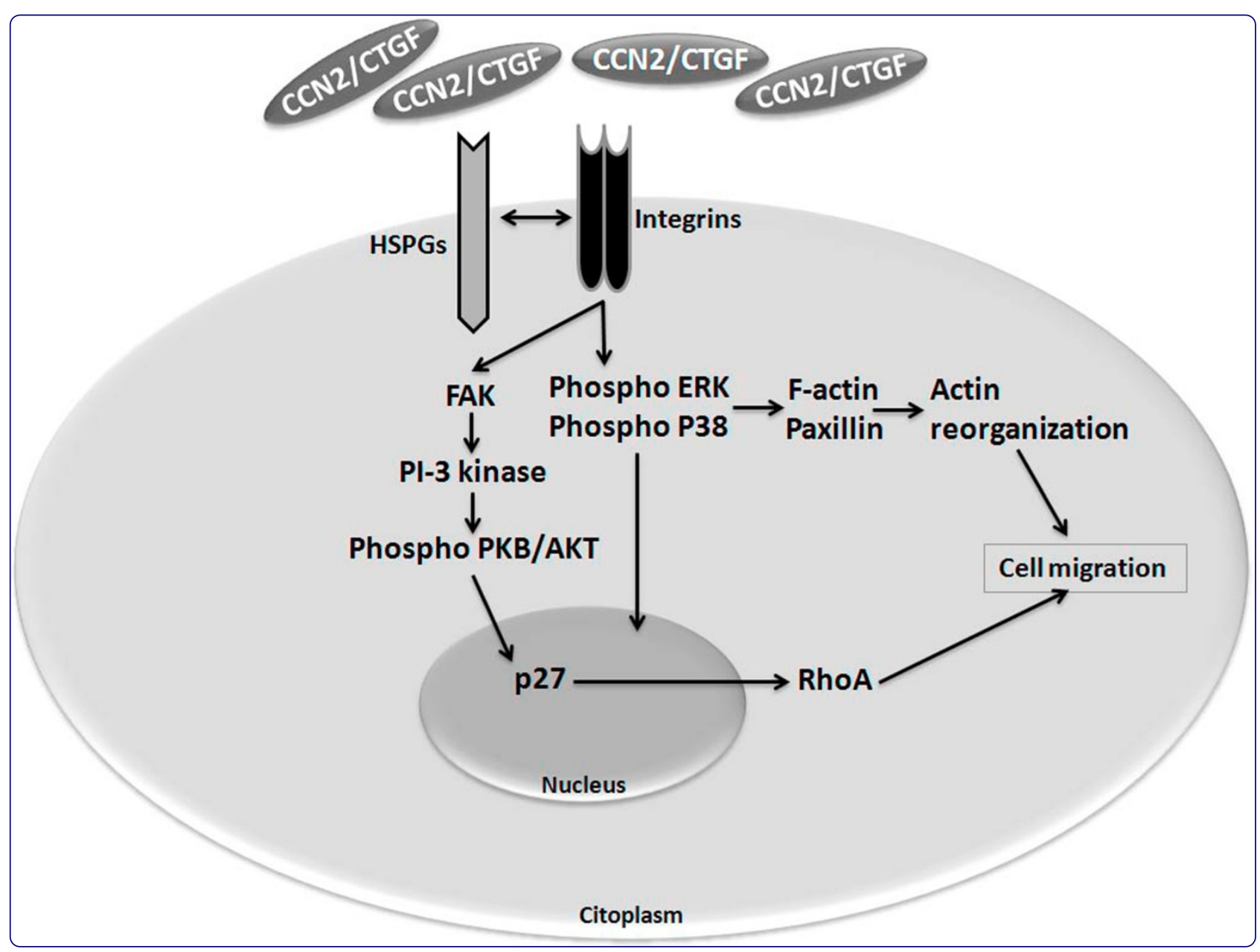

\title{
New strategy to control cell migration and metastasis regulated by CCN2/CTGF
}

Aguiar et al. 


\title{
New strategy to control cell migration and metastasis regulated by $\mathrm{CCN} 2 / \mathrm{CTGF}$
}

\author{
Diego Pinheiro Aguiar ${ }^{1 *}$, Gabriel Correa de Farias' ${ }^{1}$ Eduardo Branco de Sousa', Juliana de Mattos Coelho-Aguiar², \\ Julie Calixto Lobo ${ }^{1}$, Priscila Ladeira Casado ${ }^{1}$, Maria Eugênia Leite Duarte ${ }^{1}$ and José Garcia Ribeiro Abreu Jr
}

\begin{abstract}
Connective tissue growth factor (CTGF)/CCN family member 2 (CCN2) is a CCN family member of matricellular signaling modulators. It has been shown that CCN2/CTGF mediates cell adhesion, aggregation and migration in a large variety of cell types, including vascular endothelial cells, fibroblasts, epithelial cells, aortic smooth muscle and also pluripotent stem cells. Others matricellular proteins are capable of interacting with CCN2/CTGF to mediate its function. Cell migration is a key feature for tumor cell invasion and metastasis. CCN2/CTGF seems to be a prognostic marker for cancer. In addition, here we intend to discuss recent discoveries and a new strategy to develop therapies against CCN2/CTGF, in order to treat cancer metastasis.
\end{abstract}

Keywords: CCN2, CTGF, Adhesion, Migration and Metastasis

\section{CCN2/CTGF historical profile}

Connective tissue growth factor (CTGF)/CCN2 family member 2 (CCN2) was isolated from human endothelial cells and outlines a secreted growth factor involved in cell proliferation and chemotaxis as former described in 1991, by Dr Bradham et al. [1]. CCN2/CTGF has 349 amino acids and depending on post-translational modifications, CCN2/CTGF can be glycosylated, causing either 36 or $38 \mathrm{kDa}$, which appears as a double band on Western immunoblotting [2]. In the same year, CCN2/CTGF orthologous was described in mice and named Fisp-12 [3] or even other synonyms as BIG-M2, IGF-BP8, IGFBPrP2, HBGF-0.8, Hcs24 or ecogenin [4]. Since its identification, CCN2/CTGF's role has been studied, in a large variety of biological phenomena, especially in cell chemotaxis, migration, adhesion and cancer. Still in the nineties, other proteins with the same domains were identified, such as cysteine-rich 61 (Cyr61), nephroblastoma overexpressed (Nov), expressed in low-metastatic protein (Elm1/ Wisp-1), WNT1-inducible-signaling pathway protein-2 (Wisp-2) and WNT1-inducible-signaling pathway protein3 (Wisp-3) [5-9]. In the following decade, researches who have had contributed to the understanding of these

\footnotetext{
* Correspondence: diegopaguiar@gmail.com

${ }^{1}$ Research Division, National Institute of Traumatology and Orthopedics, Rio de Janeiro, RJ, Brazil

Full list of author information is available at the end of the article
}

proteins, proposed the unification name of these secreted factors in the CCN family (CYR61/CTGF/NOV), then called CCN1 (Cyr61), CCN2 (CTGF), CCN3 (Nov), CCN4 (Wisp-1), CCN5 (Wisp-2), and CCN6 (Wisp-3) [10]. These proteins share a multimodular structure, with a N-terminal secretory signal followed by four conserved domains with homologies to insulin-like growth factor binding proteins (Module I IGFBP), von willebrand factor type C repeat (module II VWC), thrombospondin type I repeat (Module III TSP) and a carboxy-terminal domain (Module IV - CT) containing a cystine knot [absent in CCN5] [10] (Figure 1).

Studies about the CCN family have been intensified in the last years mainly to understand CCN2/CTGF function. Several studies had also shown the relevance of each catalytic domain on proliferation and chemotaxis [1], cell fate [15], adhesion [16], and migration [17] in different cell types and tissues. Several publications had also described interactions of the CCN2/CTGF with extracellular matrix proteins [18]. Ivkovic et al. in 2003 developed a knockout mouse for CCN2/CTGF showing its role in extracellular matrix remodeling and angiogenesis during chondrogenesis [19]. In addition, CCN2/CTGF knockout mice also shows lower expression of metalloproteinase 9 and vascular endothelial growth factor (VEGF) in the growth plate. These changes lead to skeletal dimorphism, with expanded hypertrophic zones of CTGF mutant growth plates and a 


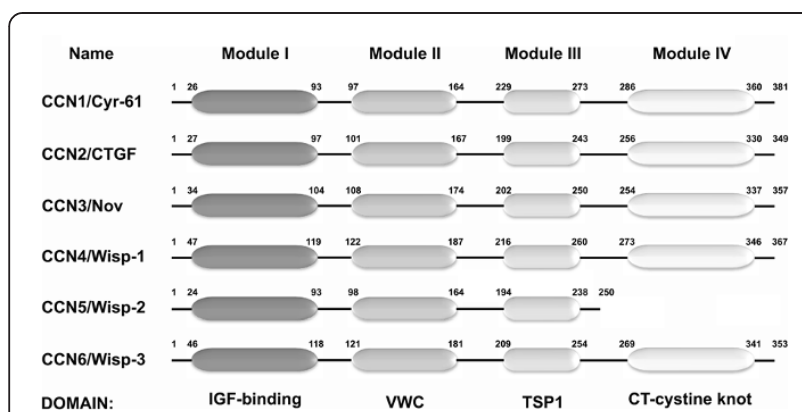

Figure 1 Schematic representation of the CCN family structure. The figure shows the current nomenclature (CCN family) and the most used name along the last years. The CCN family domains are arranged into modules as: IGF-binding/module I, WWC/module II, TSP1/module II and CT-cystine knot/module IV. The size in each domain of each CCN family member related to their biological functions [11-14]. defective replacement of cartilage by bone during endochondral ossification. This study was the first to demonstrate the role of CCN2/CTGF during development.

\section{CCN2/CTGF in cell adhesion and migration}

The synthesis of CCN2/CTGF is highly inducible by serum growth factors [20], cytokines [21], and environmental stresses such as hypoxia [22] and molecular stretch [23]. Well known inducers of CCN2/CTGF are transforming growth factor beta (TGF-beta) and VEGF $[24,25]$.

Despite researches willingness, a specific receptor for CCN2/CTGF was never described. However, several possible receptors for this growth factor had been investigated in CCN2/CTGF-mediated adhesion, migration and chemotaxis, including integrins $\left(\alpha_{6} \beta_{1}, \alpha_{\mathrm{v}} \beta_{3}, \alpha_{\mathrm{M}} \beta_{2}, \alpha_{5} \beta_{1}\right.$, $\alpha_{6} \beta_{1}, \alpha_{v} \beta_{3}, \alpha_{v} \beta_{5}, \alpha_{I I b} \beta_{3}$ and $\alpha_{3} \beta_{1}$ ) [26,27], LRP1 and LRP6 [28,29], and HSPGs (co-receptor) [30] on cell membrane (Figure 2). There are currently 89 published papers relating CCN2/CTGF to migration and adhesion, however, no one has established a CCN2/CTGF receptor (Figure 3A).

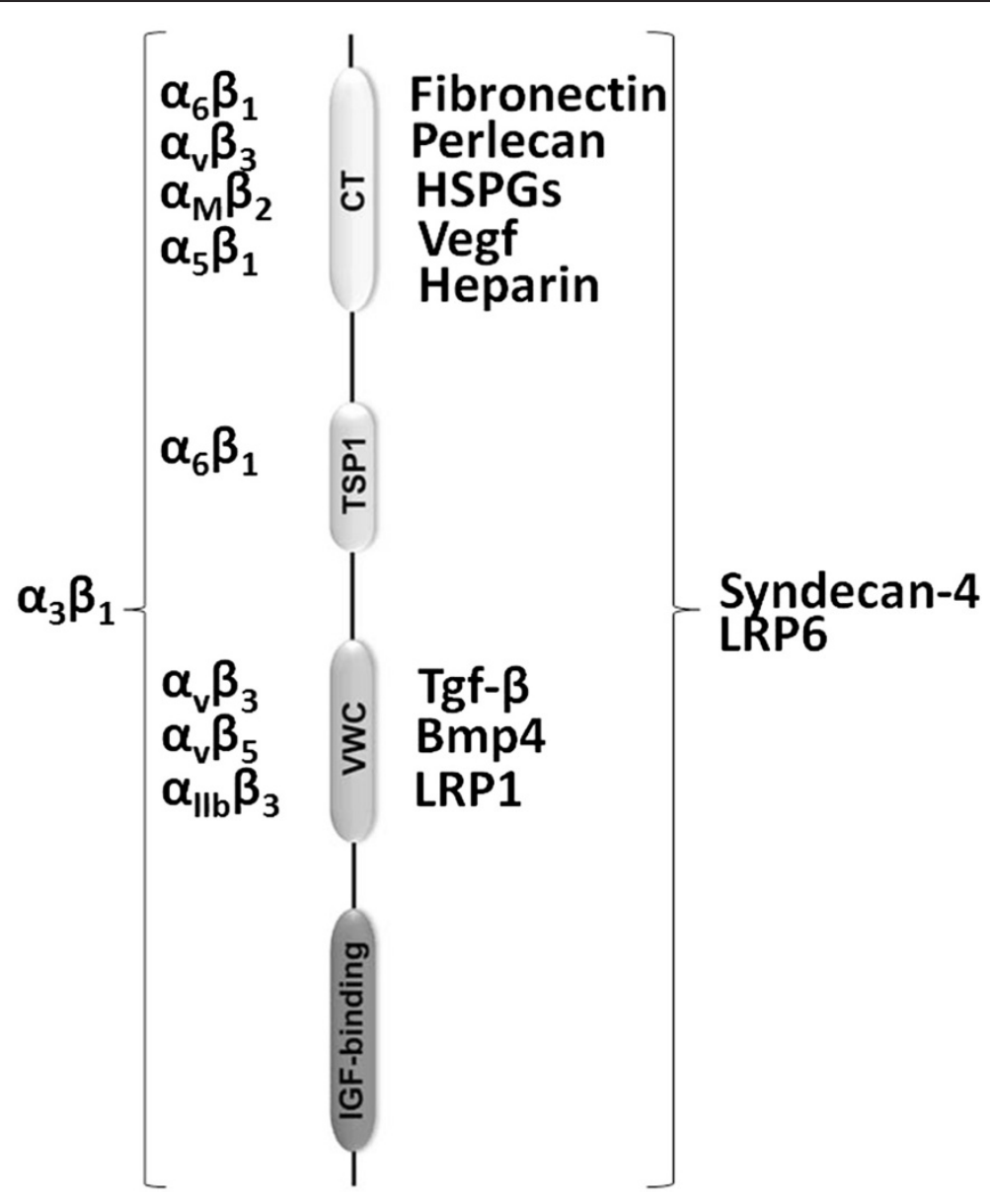

Figure 2 Interaction of CCN2/CTGF domains with other molecules. The right column shows the interaction between CCN2/CTGF with cell surface receptors, extracellular matrix and growth factors, as Fibronectin, Perlecan, HSPGs, VEGF, TGF- $\beta$, BMP4, LRP1, Heparin, Syndecan-4 [28,29,31-35]. The left column shows the interaction between CCN2/CTGF with integrins [30,36-41]. 

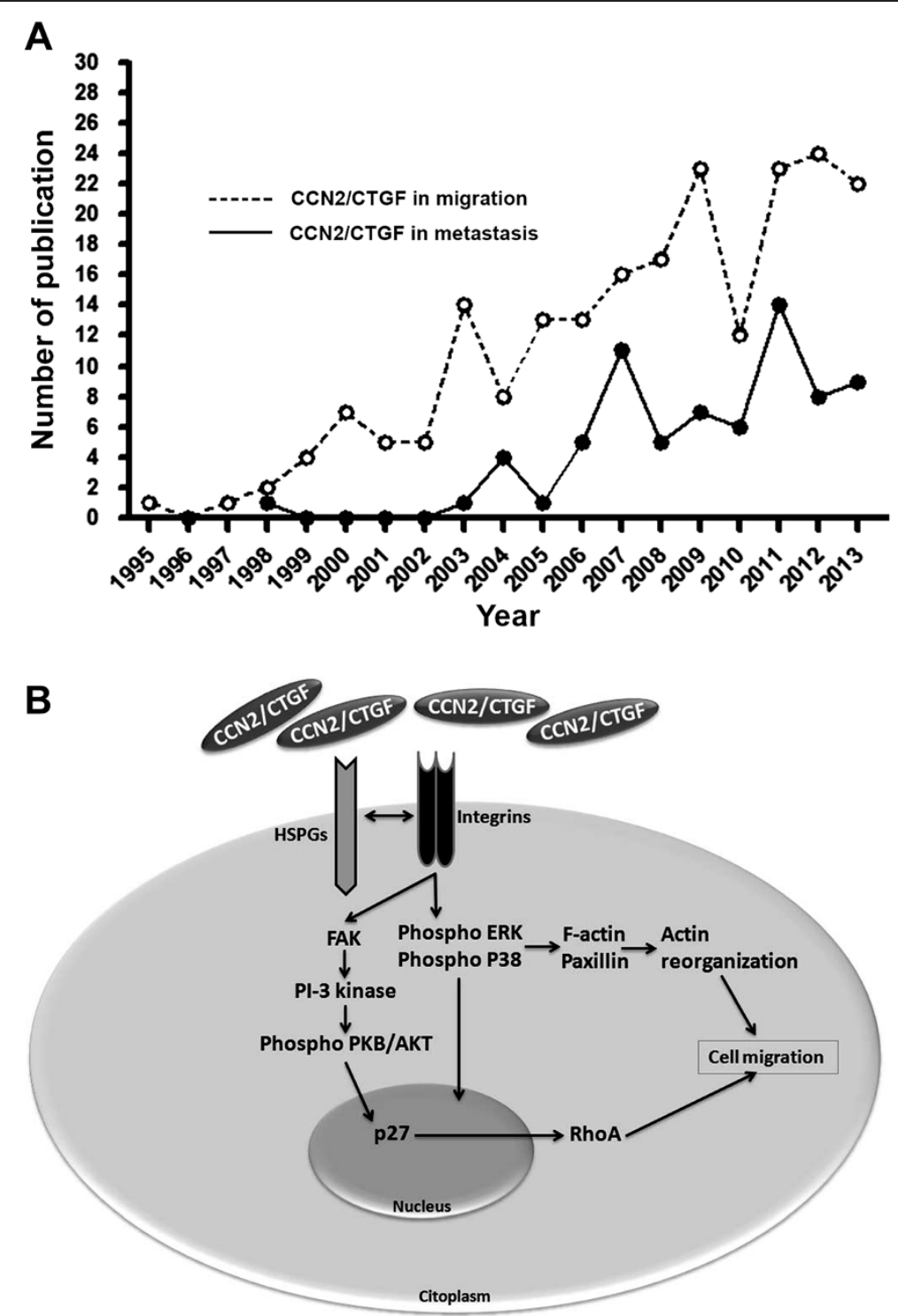

Figure 3 Impact of CCN2/CTGF research in cancer metastasis. (A) Evaluation number of articles published per year that studied the role of CCN2/CTGF on cell migration and metastasis (B) Cell migration and adhesion modulated by CCN2/CTGF. CCN2/CTGF promotes cells migration and adhesion by binding to HSPGs and Integrins in cell surface. Integrins activation potentiates the phosphorylation of the ERK and P38, leading to activation of F-actin and Paxillin resulting in actin reorganization [42]. The same pathway can stimulate FAK, PI-3 kinase ensuing phosphorylation of the PKB/AKT and translocations of P27 to the nucleus that promotes the transcriptional control of RhoA, and thus enhances focal adhesion formation and cellular migration [32].

The multiple functions of CCN2/CTGF may be explained in part by its interactions with other molecules in the extracellular domain. CCN2/CTGF binds to TGFbeta through the VWC domain and enhances its binding to TGF-beta receptor II, increasing its signaling [31,43]. A comparison of a pull of mRNA extracted from wild type mouse embryonic fibroblast (MEFs) to MEFs deleted for CCN2/CTGF(CTGF-/- MEF), both exposed to TGFbeta, showed downregulation of several molecules involved in matrix production and remodeling, cell adhesion and contraction, such as: Filamin- $\beta, \beta-$ Catenin and matrix metalloproteinase-14. These results showed CCN2/CTGF as a cofactor required to active cell adhesion by TGF-beta [44]. Since CCN2/CTGF was described to interact with other extracellular matrix proteins [45], many efforts have been made to understand how can $\mathrm{CCN} 2 / \mathrm{CTGF}$ acts in cell adhesion and migration.

An efficient way to show the role of CCN2/CTGF in cell adhesion was through the exposure of different cell types to a CCN2/CTGF-rich substrate. Thus, it was possible to show that cells exposed to CCN2/CTGF adhered to substrate faster than cells exposed only to 
free-CCN2/CTGF substrate $[46,47]$. In order to assay the role of CCN2/CTGF in cell adhesion, CCN2/CTGF coated plastic surface and anti-CCN2/CTGF antibody were used to measure cell adhesion of four different cells types: vascular endothelial cells [HUVECs and human microvascular endothelial cells (HMVECs)], fibroblasts (NIH 3T3 and AKR2B), mink lung epithelial $(\mathrm{Mv1Lu})$ cells [26,45], and human platelets [48]. All results showed that the absence of CCN2/CTGF prevents cell adhesion. In addition, the CCN2/CTGF-mediated adhesion occurs through interaction with other molecules, as fibronectin and integrins, reviewed by Arnott et al in 2011 [48]. CCN2/CTGF CT-domain interacts with fibronectin and enhances cell adhesion of chondrocytes through integrin alpha5beta1 [49]. CCN2/CTGF promotes fibroblast adhesion by binding to fibronectin, cell surface proteoglycans, and integrins that potentiates the phosphorylation on focal adhesion Kinase (FAK) and ERK and so enhances focal adhesion formation and cell spreading by F-actin, Paxilin and RhoA activation [32] (Figure 3B). Although these data suggested that CCN2/CTGF is an adhesive molecule, this property was never directly tested. However, a recent work of our research group demonstrated that CCN2/CTGF is not an adhesive molecule itself.

For the first time optical tweezers technique was used to measure the adhesion strength of different molecules. Initially, It was observed that CCN2/CTGF induced spherical cell aggregates formation when added to MvLu1 and P19 cells $[31,46,48]$. A dynamic system to assay cell aggregation to CCN2/CTGF was developed by using anti-Flag conjugated agarose beads pre-incubated with recombinant CCN2/CTGF enriched medium and added to subconfluent P19 cells cultured for $24 \mathrm{~h}$. This experiment aimed to check the local action of CCN2/CTGF on P19 cells aggregation. It was observed none or few P19 cells interacting with untreated beads. In contrast, many P19 cells were detected surrounding and adhering to CCN2/ CTGF-treated beads. The attached cells displayed morphological changes varying from a flat to an elongated shape reminiscent from the bead shape [46,48]. In this study, Boyden chamber assay indicated CCN2/CTGF as a chemoattractive molecule increasing the migration of P19 cells up to three folds [48]. In the same study, a new approach was used to measure the adhesive potential of CCN2/CTGF and to compare it with well known adhesive molecules. Using optical tweezers, we obtained quantitative parameters to evaluate molecular adhesiveness. Our data supported the CCN2/CTGF chemotactic property, although it is not an adhesive molecule for P19 cells.

\section{From innocent to guilty: CCN2/CTGF as a key molecule in metastasis}

The link between CCN2/CTGF and cell adhesion is based on protein interactions in extracellular domain, stimulus in extracellular matrix production and upregulation of adhesion pathways, but not due an own adhesive property [48]. These adhesion pathways are triggered by Integrins or MAPK activation resulting in cell attachment and detachment [50]. Knockdown of CCN2/CTGF in TW2.6 cells was shown to reduce tumor formation and decrease E-cadherin expression in xenotransplanted tumors [51]. Although there has been a huge variety of research conducted on the harmful effects of increasing levels of CCN2/CTGF, the understanding of its pathophysiology and possible modulators remain unclear. Deendooven et al. detected CCN2/CTGF levels in plasma, serum or urine in patients with fibrotic complications in consequence of hepatitis, diabetes and renal transplantation [52]. The high levels of CCN2/CTGF in these secretions suggested that it is a relevant biomarker of disorders. Furthermore, there are no efficient treatments for most disorders where the upregulation of $\mathrm{CCN} 2 / \mathrm{CTGF}$ is involved.

Taking into account the role of CCN2/CTGF on cell migration process, the expression of CCN2/CTGF has been correlated to metastasis progression. Overexpression of CCN2/CTGF was associated with invasiveness potential of the lung adenocarcinoma cells [53], and osteolytic metastasis of breast cancer [54]. Interestingly, CCN2/CTGF enhanced the motility of breast cancer cells by an integrin- $\alpha 5 \beta 3$-ERK1/2-phosphorylation [42]. In chondrosarcoma cells, CCN2/CTGF enhances cell migration by matrix metalloproteinase- 13 upregulation through integrin $\alpha 5 \beta 3$ [55] and in gastric cancer through downregulation of E-cadherin by NF- $\mathrm{kB}$ pathway [56]. Curiously, neutralizing anti-CCN2/CTGF antibody attenuated metastasis pancreatic cancer [57]. In cancer and in metastasis, the role of $\mathrm{CCN} 2 / \mathrm{CTGF}$ seems to be the same. In the last years, the number of studies showing CCN2/ CTGF involved in migration and metastasis has increased. The treatment of patients with metastasis is not efficient. For this reason, the occurrence of metastasis in cancer is an important issue nowadays, and CCN2/CTGF could be an important target for its attenuation or prevention.

\section{CCN2/CTGF a challenge for the future: Where will we go?}

In order to develop specific treatments for disorders where CCN2/CTGF are upregulated, as metastasis, CCN2/CTGF shutdown by epigenetic modulation may be an effective strategy. In general, DNA methylation patterns are established and modified in response to environmental factors by DNA methyl-transferases (DNMTs) which inhibits gene transcription and regulates gene expression [58]. Therefore, inhibition of CCN2/CTGF expression in specific diseases could be achieved by increasing DNA methylation of the CCN2/CTGF gene on promoter region. DNA methylation of the CCN2/CTGF genomic sequence has already been reported in several cancers 


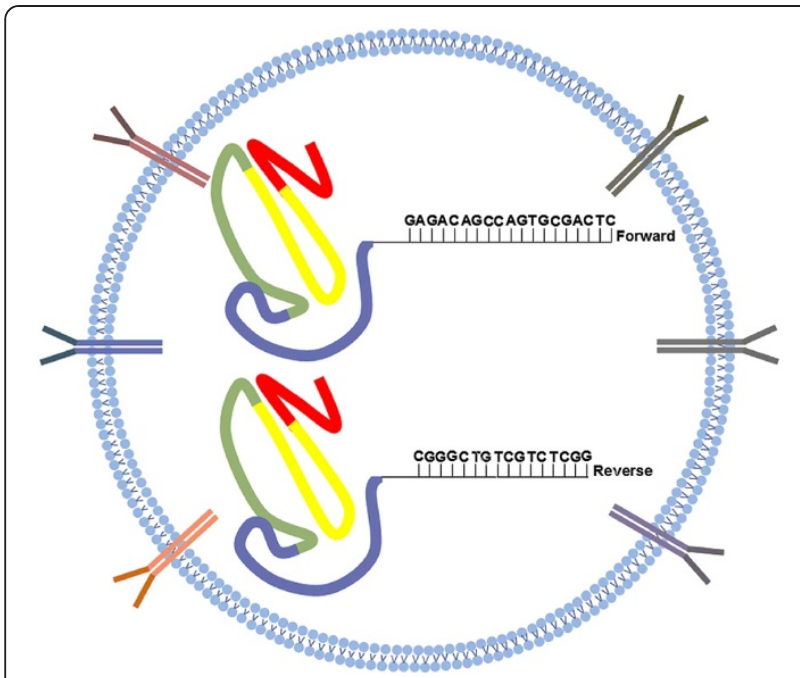

Figure 4 Repression of CCN2/CTGF transcription by methylation. Antibodies distributed over the membrane of the liposome vesicle, could be used to recognize target cells as: Ovarian tumor cells, breast tumor cells or hiperproliferative fibroblast during wound healing. It might allow more specificity in the blockage. The DNA methyl-transferase enzyme linked to specific primer for CCN2/ CTGF promoter region is located inside the lipofection body. The rational allow us to imagine that CCN2/CTGF gene hipermethylation will promote its downexpression. CCN2/CTGF Primers forward 5' GAGACAGCCAGTGCGACTC 3' Reverse 3' CGGGCTGTCGTCTCGG 5'.

$[59,60]$, but a detailed target sequence for DNA methylation contributing for gene silencing had never been described. The mechanisms of CCN2/CTGF expression remain unknown. The delivery of DNA methyl-transferase enzyme linked to specific primer for CCN2/CTGF in promoter region directs to the target cell, through antibodies that recognize specifically target cell, could be explored as a way to silence CCN2/CTGF. This blockage-pack would have a DNMT linked to CCN2/CTGF primers (Forward and Reverse sense) designed to its promoter region. DNMT would hypermethylate the CCN2/CTGF promoter region and $\mathrm{CpG}$ islands will be increased leading to CCN2/CTGF donwregulation (Figure 4). A homozygous deletion of CCN2/CTGF at human chromosome 6q23.2 by hypermethylation could be used or breast cancer cells, for example. It would be useful to block its expression and then decrease cancer metastasis. Our proposed DNA methylation strategy on promoter region of CCN2/CTGF gene to control its expression would certainly control all chain reactions triggered by this growth factor. We hope that in the future, alike strategies that could be used to block target gene transcription and, consequently, inhibit its migration and adhesion by preventing several disorders as metastasis, fibrosis or tissue remodeling.

\section{Competing interests}

The authors declare that they have no competing interests.

\section{Authors' contributions}

DPA and JGRAJr conceived the idea. DPA and JMCA integrated different points of literatures and drafted the manuscript. GCF, EBS, JCL, PLC, and MELD did literature research on specific points, and got involved in discussion. All authors read and approved the final manuscript.

\section{Author details}

${ }^{1}$ Research Division, National Institute of Traumatology and Orthopedics, Rio de Janeiro, RJ, Brazil. ²Program of Cell and Developmental Biology, Institute of Biomedical Sciences, Federal University of Rio de Janeiro, Rio de Janeiro, RJ, Brazil.

Received: 15 April 2014 Accepted: 21 June 2014

Published: 12 July 2014

\section{References}

1. Bradham DM, Igarashi A, Potter RL, Grotendorst GR: Connective tissue growth factor: a cysteine-rich mitogen secreted by human vascular endothelial cells is related to the SRC-induced immediate early gene product CEF-10. J Cell Biol 1991, 114:1285-1294.

2. Phanish MK, Winn SK, Dockrell ME: Connective tissue growth factor-(CTGF, CCN2)-a marker, mediator and therapeutic target for renal fibrosis. Nephron Exp Nephrol 2010, 114:83-92.

3. Ryseck RP, Macdonald-Bravo H, Mattei MG, Bravo R: Structure, mapping, and expression of fisp-12, a growth factor-inducible gene encoding a secreted cysteine-rich protein. Cell Growth Differ 1991, 2:225-233.

4. Moussad EE, Brigstock DR: Connective tissue growth factor: what's in a name? Mol Genet Metab 2000, 71:276-292.

5. O'Brien TP, Yang GP, Sanders L, Lau LF: Expression of cyr61, a growth factor-inducible immediate-early gene. Mol Cell Biol 1990, 10:3569-3577.

6. Martinerie C, Viegas-Pequignot E, Guenard I, Dutrillaux B, Nguyen VC, Bernheim A, Perbal B: Physical mapping of human loci homologous to the chicken nov proto-oncogene. Oncogene 1992, 7:2529-2534.

7. Blacketer MJ, Koehler CM, Coats SG, Myers AM, Madaule P: Regulation of dimorphism in Saccharomyces cerevisiae: involvement of the novel protein kinase homolog Elm1p and protein phosphatase 2A. Mol Cell Biol 1993, 13:5567-5581.

8. Zhang R, Averboukh L, Zhu W, Zhang H, Jo H, Dempsey PJ, Coffey RJ, Pardee $A B$, Liang P: Identification of $r C o p-1$, a new member of the $C C N$ protein family, as a negative regulator for cell transformation. Mol Cell Biol 1998, 18:6131-6141.

9. Hurvitz JR, Suwairi WM, Van Hul W, El-Shanti H, Superti-Furga A, Roudier J, Holderbaum D, Pauli RM, Herd JK, Van Hul EV, Rezai-Delui H, Legius E, Le Merrer M, Al-Alami J, Bahabri SA, Warman ML: Mutations in the CCN gene family member WISP3 cause progressive pseudorheumatoid dysplasia. Nat Genet 1999, 23:94-98.

10. Brigstock DR, Goldschmeding R, Katsube Kl, Lam SC, Lau LF, Lyons K, Naus C, Perbal B, Riser B, Takigawa M, Yeger H: Proposal for a unified CCN nomenclature. Mol Pathol 2003, 56:127-128.

11. Kim HS, Nagalla SR, Oh Y, Wilson E, Roberts CT Jr, Rosenfeld RG: Identification of a family of low-affinity insulin-like growth factor binding proteins (IGFBPs): characterization of connective tissue growth factor as a member of the IGFBP superfamily. Proc Natl Acad Sci U S A 1997, 94:12981-12986.

12. Grotendorst GR, Lau LF, Perbal B: CCN proteins are distinct from and should not be considered members of the insulin-like growth factor-binding protein superfamily. Endocrinology 2000, 141:2254-2256.

13. Collet C, Candy J: How many insulin-like growth factor binding proteins? Mol Cell Endocrinol 1998, 139:1-6.

14. Baxter RC, Binoux MA, Clemmons DR, Conover CA, Drop SL, Holly JM, Mohan S, Oh Y, Rosenfeld RG: Recommendations for nomenclature of the insulin-like growth factor binding protein superfamily. J Clin Endocrinol Metab 1998, 83:3213.

15. Mason ED, Konrad KD, Webb CD, Marsh $J$ : Dorsal midline fate in Drosophila embryos requires twisted gastrulation, a gene encoding a secreted protein related to human connective tissue growth factor. Genes Dev 1994, 8:1489-1501.

16. Kothapalli D, Frazier KS, Welply A, Segarini PR, Grotendorst GR: Transforming growth factor beta induces anchorage-independent growth of NRK fibroblasts via a connective tissue growth factor-dependent signaling pathway. Cell Growth Differ 1997, 8:61-68. 
17. Shimo T, Nakanishi T, Kimura Y, Nishida T, Ishizeki K, Matsumura T, Takigawa $M$ : Inhibition of endogenous expression of connective tissue growth factor by its antisense oligonucleotide and antisense RNA suppresses proliferation and migration of vascular endothelial cells. J Biochem 1998 124:130-140.

18. Chen CC, Lau LF: Functions and mechanisms of action of CCN matricellular proteins. Int J Biochem Cell Biol 2009, 41:771-783.

19. Ivkovic S, Yoon BS, Popoff SN, Safadi FF, Libuda DE, Stephenson RC, Daluiski A, Lyons KM: Connective tissue growth factor coordinates chondrogenesis and angiogenesis during skeletal development. Development 2003, 130:2779-2791.

20. Pandey DP, Lappano R, Albanito L, Madeo A, Maggiolini M, Picard D: Estrogenic GPR30 signalling induces proliferation and migration of breast cancer cells through CTGF. EMBO J 2009, 28:523-532.

21. Igarashi A, Okochi H, Bradham DM, Grotendorst GR: Regulation of connective tissue growth factor gene expression in human skin fibroblasts and during wound repair. Mol Biol Cell 1993, 4:637-645.

22. Shimo T, Kubota S, Kondo S, Nakanishi T, Sasaki A, Mese H, Matsumura T, Takigawa M: Connective tissue growth factor as a major angiogenic agent that is induced by hypoxia in a human breast cancer cell line. Cancer Lett 2001, 174:57-64.

23. Chaqour B, Yang R, Sha Q: Mechanical stretch modulates the promoter activity of the profibrotic factor CCN2 through increased actin polymerization and NF-kappaB activation. J Biol Chem 2006, 281:20608-20622.

24. Holmes A, Abraham DJ, Sa S, Shiwen X, Black CM, Leask A: CTGF and SMADs, maintenance of scleroderma phenotype is independent of SMAD signaling. J Biol Chem 2001, 276:10594-10601.

25. Suzuma K, Naruse K, Suzuma I, Takahara N, Ueki K, Aiello LP, King GL: Vascular endothelial growth factor induces expression of connective tissue growth factor via KDR, Flt1, and phosphatidylinositol 3-kinase-akt-dependent pathways in retinal vascular cells. J Bio/ Chem 2000, 275:240725-240731.

26. Babic AM, Chen CC, Lau LF: Fisp12/mouse connective tissue growth factor mediates endothelial cell adhesion and migration through integrin alphavbeta3, promotes endothelial cell survival, and induces angiogenesis in vivo. Mol Cell Biol 1999, 19:2958-2966.

27. Schober JM, Chen N, Grzeszkiewicz TM, Jovanovic I, Emeson EE, Ugarova TP, Ye RD, Lau LF, Lam SC: Identification of integrin alpha (M) beta (2) as an adhesion receptor on peripheral blood monocytes for Cyr61 (CCN1) and connective tissue growth factor (CCN2): immediate-early gene products expressed in atherosclerotic lesions. Blood 2002, 99:4457-4465.

28. Mercurio S, Latinkic B, Itasaki N, Krumlauf R, Smith JC: Connective-tissue growth factor modulates WNT signalling and interacts with the WNT receptor complex. Development 2004, 131:2137-2147.

29. Gao R, Brigstock DR: Low density lipoprotein receptor-related protein (LRP) is a heparin-dependent adhesion receptor for connective tissue growth factor (CTGF) in rat activated hepatic stellate cells. Hepatol Res 2003, 27:214-220.

30. Gao R, Brigstock DR: Connective tissue growth factor (CCN2) induces adhesion of rat activated hepatic stellate cells by binding of its $\mathrm{C}$ terminal domain to integrin alpha (v) beta (3) and heparan sulfate proteoglycan. J Biol Chem 2004, 279:8848-8855.

31. Abreu JG, Ketpura NI, Reversade B, De Robertis EM: Connective-tissue growth factor (CTGF) modulates cell signalling by BMP and TGF-beta. Nat Cell Biol 2002, 4:599-604.

32. Chen Y, Abraham DJ, Shi-Wen X, Pearson JD, Black CM, Lyons KM, Leask A: CCN2 (connective tissue growth factor) promotes fibroblast adhesion to fibronectin. Mol Biol Cell 2004, 15:5635-5646

33. Ball DK, Rachfal AW, Kemper SA, Brigstock DR: The heparin-binding $10 \mathrm{kDa}$ fragment of connective tissue growth factor (CTGF) containing module 4 alone stimulates cell adhesion. J Endocrinol 2003, 176:R1-R7.

34. Inoki I, Shiomi T, Hashimoto G, Enomoto H, Nakamura H, Makino K, Ikeda E, Takata S, Kobayashi K, Okada Y: Connective tissue growth factor binds vascular endothelial growth factor (VEGF) and inhibits VEGF-induced angiogenesis. FASEB J 2002, 16:219-221.

35. Nishida T, Kubota S, Fukunaga T, Kondo S, Yosimichi G, Nakanishi T, Takano-Yamamoto T, Takigawa M: CTGF/Hcs24, hypertrophic chondrocyte-specific gene product, interacts with perlecan in regulating the proliferation and differentiation of chondrocytes. J Cell Physiol 2003, 196:265-275.
36. Heng EC, Huang Y, Black SA Jr, Trackman PC: CCN2, connective tissue growth factor, stimulates collagen deposition by gingival fibroblasts via module 3 and alpha6- and beta1 integrins. J Cell Biochem 2006, 98:409-420.

37. Chen N, Chen CC, Lau LF: Adhesion of human skin fibroblasts to Cyr61 is mediated through integrin alpha 6beta 1 and cell surface heparan sulfate proteoglycans. J Biol Chem 2000, 275:24953-24961.

38. Leu SJ, Chen N, Chen CC, Todorovic V, Bai T, Juric V, Liu Y, Yan G, Lam SC, Lau LF: Targeted mutagenesis of the angiogenic protein CCN1 (CYR61). Selective inactivation of integrin alpha6beta1-heparan sulfate proteoglycan coreceptor-mediated cellular functions. J Biol Chem 2004, 279:44177-44187.

39. Leu SJ, Liu Y, Chen N, Chen CC, Lam SC, Lau LF: Identification of a novel integrin alpha 6 beta 1 binding site in the angiogenic inducer CCN1 (CYR61). J Biol Chem 2003, 278:33801-33808.

40. Gao R, Brigstock DR: A novel integrin alpha5beta1 binding domain in module 4 of connective tissue growth factor (CCN2/CTGF) promotes adhesion and migration of activated pancreatic stellate cells. Gut 2006, 55:856-862.

41. Lau LF, Lam SC: The CCN family of angiogenic regulators: the integrin connection. Exp Cell Res 1999, 248:44-57.

42. Chen PS, Wang MY, Wu SN, Su JL, Hong CC, Chuang SE, Chen MW, Hua KT, Wu YL, Cha ST, Babu MS, Chen CN, Lee PH, Chang KJ, Kuo ML: CTGF enhances the motility of breast cancer cells via an integrin-alphavbeta3ERK1/2-dependent S100A4-upregulated pathway. J Cell Sci 2007, 120:2053-2065.

43. Khankan R, Oliver N, He S, Ryan SJ, Hinton DR: Regulation of fibronectin-EDA through CTGF domain-specific interactions with TGF \{beta\} 2 and its receptor TGF \{beta\} RII. Invest Ophthalmol Vis Sci 2011, 52:5068-5078.

44. Shi-wen X, Stanton LA, Kennedy L, Pala D, Chen Y, Howat SL, Renzoni EA, Carter DE, Bou-Gharios G, Stratton RJ, Pearson JD, Beier F, Lyons KM, Black CM, Abraham DJ, Leask A: CCN2 is necessary for adhesive responses to transforming growth factor-beta1 in embryonic fibroblasts. J Biol Chem 2006, 281:10715-10726.

45. Kireeva ML, Latinkic BV, Kolesnikova TV, Chen CC, Yang GP, Abler AS, Lau LF: Cyr61 and Fisp12 are both ECM-associated signaling molecules: activities, metabolism, and localization during development. Exp Cell Res 1997, 233:63-77.

46. Aguiar DP, Coelho-Aguiar JM, Abreu JG: CCN2/CTGF silencing blocks cell aggregation in embryonal carcinoma P19 cell. Braz J Med Biol Res 2011a, 44:200-205.

47. Aguiar DP, Pontes B, Mendes FA, Andrade LR, Viana NB, Abreu JG: CTGF/CCN2 has a chemoattractive function but a weak adhesive property to embryonic carcinoma cells. Biochem Biophys Res Commun 2011, 413:582-587.

48. Arnott JA, Lambi AG, Mundy C, Hendesi H, Pixley RA, Owen TA, Safadi FF, Popoff SN: The role of connective tissue growth factor (CTGF/CCN2) in skeletogenesis. Crit Rev Eukaryot Gene Expr 2011, 21:43-69.

49. Jedsadayanmata A, Chen CC, Kireeva ML, Lau LF, Lam SC: Activationdependent adhesion of human platelets to Cyr61 and Fisp12/mouse connective tissue growth factor is mediated through integrin alpha (Ilb) beta (3). J Biol Chem 1999, 274:24321-24327.

50. Hoshijima M, Hattori T, Inoue M, Araki D, Hanagata H, Miyauchi A, Takigawa M: CT domain of CCN2/CTGF directly interacts with fibronectin and enhances cell adhesion of chondrocytes through integrin alpha5beta1. FEBS Lett 2006, 580:1376-1382.

51. Gu J, Liu X, Wang QX, Tan HW, Guo M, Jiang WF, Zhou L: Angiotensin II increases CTGF expression via MAPKs/TGF- $\beta 1 /$ TRAF6 pathway in atrial fibroblasts. Exp Cell Res 2012, 318:2105-15.

52. Chang CC, Hsu WH, Wang CC, Chou CH, Kuo MY, Lin BR, Chen ST, Tai SK, Kuo ML, Yang MH: Connective tissue growth factor activates Pluripotency genes and Mesenchymal-Epithelial Transition in head and neck cancer cells. Cancer Res 2013, 73:4147-4157.

53. Dendooven A, Nguyen TQ, Brosens L, Li D, Tarnow L, Parving HH, Rossing P, Goldschmeding R: The CTGF -945GC polymorphism is not associated with plasma CTGF and does not predict nephropathy or outcome in type 1 diabetes. J Negat Results Biomed 2011, 8:10. 4.

54. Chang CC, Shih JY, Jeng YM, Su JL, Lin BZ, Chen ST, Chau YP, Yang PC, Kuo $\mathrm{ML}$ : Connective tissue growth factor and its role in lung adenocarcinoma invasion and metastasis. J Natl Cancer Inst 2004, 96:364-375.

55. Shimo T, Kubota S, Yoshioka N, Ibaragi S, Isowa S, Eguchi T, Sasaki A, Takigawa M: Pathogenic role of connective tissue growth factor (CTGF/ 
CCN2) in osteolytic metastasis of breast cancer. J Bone Miner Res 2006, 21:1045-1059.

56. Tan TW, Lai CH, Huang CY, Yang WH, Chen HT, Hsu HC, Fong YC, Tang CH: CTGF enhances migration and MMP-13 up-regulation via alphavbeta3 integrin. FAK, ERK, and NF-kappaB-dependent pathway in human chondrosarcoma cells. J Cell Biochem 2009, 107:345-356.

57. Mao Z, Ma X, Rong Y, Cui L, Wang X, Wu W, Zhang J, Jin D: Connective tissue growth factor enhances the migration of gastric cancer through downregulation of E-cadherin via the NF-kappaB pathway. Cancer Sci 2011, 102:104-110.

58. Aikawa T, Gunn J, Spong SM, Klaus SJ, Korc M: Connective tissue growth factor-specific antibody attenuates tumor growth, metastasis, and angiogenesis in an orthotopic mouse model of pancreatic cancer. Mol Cancer Ther 2006, 5:1108-1116.

59. Heyn H, Vidal E, Sayols S, Sanchez-Mut JV, Moran S, Medina I, Sandoval t, Simó-Riudalbas L, Szczesna K, Huertas D, Gatto S, Matarazzo MR, Dopazo J, Esteller M: Whole-genome bisulfite DNA sequencing of a DNMT3B mutant patient. Epigenetics 2012, 7:542-50.

60. Chiba T, Yokosuka O, Fukai K, Hirasawa Y, Tada M, Mikata R, Imazeki F, Taniguchi H, Iwama A, Miyazaki M, Ochiai T, Saisho H: Identification and investigation of methylated genes in hepatoma. Eur J Cancer 2005, 41:1185.

doi:10.1186/1475-2867-14-61

Cite this article as: Aguiar et al:: New strategy to control cell migration and metastasis regulated by CCN2/CTGF. Cancer Cell International 2014 14:61

\section{Submit your next manuscript to BioMed Central and take full advantage of:}

- Convenient online submission

- Thorough peer review

- No space constraints or color figure charges

- Immediate publication on acceptance

- Inclusion in PubMed, CAS, Scopus and Google Scholar

- Research which is freely available for redistribution 